\title{
PENGARUH PAPARAN SINAR MATAHARI PAGI TERHADAP PENURUNAN TANDA IKTERUS PADA IKTERUS NEONATORUM FISIOLOGIS
}

\section{THE EFFECT OF MORNING SUN EXPOSURE TO DECREASING LEVEL OF JAUNDICE SKIN IN PHYSIOLOGICAL JAUNDICE}

\author{
Ratih Dewi Puspitosari *, Sumarno**, Budi Susatia *** \\ * Program Studi IImu Keperawatan Fakultas Kedokteran Universitas Brawijaya Malang \\ ** Laboratorium Mikrobiologi Fakultas Kedokteran Universitas Brawijaya Malang \\ ${ }^{* * *}$ Politeknik Kesehatan Jurusan Keperawatan Malang
}

\begin{abstract}
Physiological jaundice is a sign usually happens to newborn infants. The cause of icterus is the increase of indirect bilirubin that makes the skin yellow that usually disturb the people. Treatment of this yellow baby is by exposing them to the morning sun. Sun exposure can reduce jaundice skin by changing the bilirubin indirect molecule. This research aim was to know the effect of morning sun exposure that can decrease jaundice skin through jaundice skin level measurement on babies. The special goal of the research was to know the jaundice skin and the difference before and after expos to the sun. The research was a quasi experimental study. The samples consisted of 5 babies, selected by quota sampling. The measured variables were morning sun exposure and jaundice skin level. The research was done by exposing the samples on the morning sun for 30 minutes, then the jaundice skin measured in minutes $0,5^{\text {th }}, 10^{\text {th }}, 15^{\text {th }}$, $20^{\text {th }}, 25^{\text {th }}$, and $30^{\text {th }}$ by using Corel Photo-Paint 12 Program. Data analysis was done with ANOVA and was continued by correlation-regression test, with confidence interval 99\%. Research result showed a significant correlation of sun exposure to jaundice skin level $(p<0,01)$, and also predicted that the longer the sun exposure given to newborn infants the less jaundice skin level in the body in an estimate value of 1.276 per minute. The conclusion is: there's an effect of morning sun exposure to decreasing level of jaundice skin in physiologic jaundice, and the effective timing of sun exposure is 30 minutes, and Corel Photo-Paint 12 program is able to be used as a method to measure jaundice skin level.
\end{abstract}

Key words: sun exposure, Jaundice skin, Physiological jaundice

\section{PENDAHULUAN}

Ikterus adalah suatu gejala yang sering ditemukan pada bayi baru lahir. Semua bayi baru lahir akan mengalami proses "menjadi kuning" yang disebut sebagai ikterus neonatorum. Kejadian ikterus pada bayi baru lahir menurut beberapa penulis berkisar antara $50 \%$ pada bayi cukup bulan dan $75 \%$ pada bayi lahir kurang bulan. Sedangkan beberapa penulis lain menyebutkan bahwa angka kejadian ikterus dapat ditemukan pada minggu pertama kehidupan pada sekitar $60 \%$ bayi cukup bulan dan $80 \%$ bayi kurang bulan $(1,2$, $3,4)$. Menurut Yong (2001) ikterus neonatorum ini merupakan suatu hal atau perkara yang biasa pada masa kini (4).

Ikterus yang dialami oleh sebagian besar bayi baru lahir ini merupakan ikterus yang fisiologis, memiliki derajat ringan, yang terjadi karena adanya peningkatan bilirubin bebas (indirect) di dalam darah neonatus. Bilirubin ini merupakan hasil metabolisme hemoglobin yang terkandung di dalam sel darah merah, sel darah merah ini memiliki usia

Jurnal Kedokteran Brawijaya, Vol. XXII, No. 3, Desember 2006 Korespondensi: Sumarno; Laboratorium Biomedik FK Unibraw; Jl. Veteran Malang; (0341) 580993 ext 128 tertentu, 120 hari pada manusia dewasa, dan sekitar 70-90 hari pada neonatus. Usia sel darah merah yang pendek ini terjadi karena kondisi sel darah merah neonatus yang masih sangat muda (immature), selnya berinti besar sehingga sangat mudah mengalami hemolisis (pemecahan). Apabila mencapai masanya, sel darah merah ini akan mengalami destruksi atau pemecahan. Sebagai manifestasinya, akan terjadi akumulasi bilirubin bebas dalam darah neonatus yang umumnya akan terlihat pada kulit, lapisan mukosa lainnya, serta sklera mata. Hal ini disebabkan karena bilirubin bebas larut dalam lemak, padahal konsentrasi lemak banyak terdapat di lapisan subkutan, sehingga bilirubin akan terlarut disana dan tampak sebagai "penyakit kuning". Sedangkan ikterus patologis, misalnya ikterus karena septikemia, hipotiroid, atau ketidakserasian $A B O$, lebih sedikit ditemukan pada bayi baru lahir, namun apabila ikterus ini tidak dikontrol dengan baik, dapat memicu terjadinya sindroma neurologik, yang dikenal dengan nama Kern icterus, yang timbul sebagai akibat penimbunan bilirubin bebas di dalam sel-sel otak, yang kandungan terbesarnya adalah lemak, dan dapat menimbulkan kematian pada bayi. 
Penanganan ikterus neonatorum dapat dilakukan dengan berbagai cara sesuai dengan jenisnya. Untuk ikterus neonatorum patologis akan ditangani dengan beberapa cara, yaitu: pemberian obat, transfusi tukar darah (exchange transfusion), dan fototerapi yang dilakukan selama $2 \times 24$ jam sampai $3 \times 24$ jam di rumah sakit. Namun untuk fototerapi tidak semua rumah sakit memiliki alat ini, sedangkan di lain pihak, biaya yang diperlukan untuk fototerapi tidaklah murah, terutama bagi para orang tua yang kurang mampu. Oleh karena itu, fenomena di masyarakat yang dapat kita amati, apabila menjumpai "penyakit kuning" yang sangat mengganggu bagi masyarakat ini, akan dilakukan penanganan dengan cara menjemur bayi tersebut dibawah sinar matahari. Konon, masyarakat meyakini bahwa tindakan tersebut akan dapat menghilangkan "kuning" pada bayi baru lahir tersebut. Belum ada penelitian yang mempelajari efek sinar matahari terhadap tanda ikterus neonatorum.

Perubahan tanda ikterus yang dapat ditemukan terutama pada kulit maupun sklera mata, dengan manifesttasi yaitu memberikan warna kuning, akan dapat dianalisis dengan mengamati perubahannya. Analisis ini dilakukan dengan cara mengamati perubahan konsentrasi warna kuning pada bayi, sebelum dan sesudah dilakukan penjemuran di bawah sinar matahari pagi. Perubahan konsentrasi warna ini dapat terjadi karena sinar biru yang terkandung di dalam sinar matahari akan mengubah bilirubin bebas menjadi fotoisomer yang larut dalam air, sehingga bilirubin akan dapat dikeluarkan melalui saluran pencernaan tanpa melalui proses konjugasi dan pada akhirnya akan mengurangi konsentrasi warna kuning yang tampak pada lapisan mukosa, kulit maupun sklera mata bayi. Selanjutnya, konsentrasi warna ini akan dianalisis dengan program Corel Photo-Paint 12.

Tujuan penelitian ini adalah mempelajari pengaruh paparan sinar matahari pagi terhadap penurunan tanda ikterus pada ikterus neonatorum fisiologis. Manfaat penelitian ini antara lain dapat digunakan untuk meningkatkan pemahaman tentang pengaruh sinar matahari pagi terhadap penurunan tanda ikterus pada ikterus neonatorum fisiologis, dapat digunakan sebagai bahan pertimbangan dalam menanggulangi ikterus neonatorum fisiologis, dapat digunakan sebagai dasar untuk melakukan intervesi keperawatan dengan menjemur bayi dibawah sinar matahari pagi pada ikterus neonatorum fisiologis, dan dapat digunakan sebagai data dasar untuk melaksanakan penelitian selanjutnya yang berkaitan dengan pengaruh sinar matahari pagi terhadap penurunan tanda ikterus pada ikterus neonatorum fisiologis

\section{METODE}

Jenis penelitian yang dilakukan pada penelitian ini adalah quasi experimental (eksperimental semu). Desain ini belum atau tidak memiliki ciri-ciri rancangan eksperimen yang sebenarnya karena adanya variabel-variabel yang seharusnya dikontrol atau dimanipulasi (5). Adapun pengujian dilakukan dengan uji ANOVA untuk mengetahui perbedaan pada setiap variasi waktu perlakuan, dilanjutkan dengan uji korelasi untuk mengetahui pengaruh suatu variabel terhadap variabel yang lain, dan dengan uji regresi untuk mengetahui seberapa besar pengaruh yang ditimbulkan. Pada penelitian ini subjek yang sama akan diperiksa pada pra dan pasca intervensi (desain before and after) $(6,7)$.

Populasi pada penelitian ini adalah semua bayi baru lahir (neonatus) yang berusia kurang dari satu minggu atau tujuh hari, yang positif mengalami ikterus fisiologis. Sedangkan sampel penelitian merupakan sebagian dari jumlah populasi yang sudah ditentukan, untuk selanjutnya digunakan sebagai subjek penelitian, dan memenuhi kriteria inklusi untuk sampel seperti:

- bayi baru lahir berusia 0-1 minggu

- suku Jawa

- tanda ikterus (kuning) muncul pada hari kedua atau ketiga setelah lahir

- identifikasi warna kuning dilakukan oleh bidan yang menolong persalinan

- ibu tidak mengkonsumsi fenobarbital selama kehamilan

- bersedia untuk diteliti (mengisi informed consent)

Adapun kriteria inklusi sinar matahari yang digunakan dalam penelitian ini adalah:

- sinar matahari pagi, pada pukul 06.00-07.00

- cuaca serah, tidak mendung, tidak hujan, tidak berangin

Sedangkan kriteria pengambilan gambar (foto) adalah:

- bayi dijemur dibawah sinar matahari pagi dengan menggunakan pakaian, namun penutup kepala dilepaskan

- bayi dihadapkan pada posisi membelakangi sinar matahari agar paparan sinar tidak langsung mengenai mata bayi

- gambar (foto) diambil sebelum dan setelah dijemur dengan memijit dan meregangkan area yang akan difoto (agar warna kuning lebih terlihat), lalu area tersebut difoto dengan menggunakan kamera digital tanpa pencahayaan (blitz) kamera

- area tubuh yang difoto adalah pipi dan dada

- foto-foto tersebut kemudian diolah dengan program Corel Photo-Paint 12 dengan teknik replikasi sehingga diperoleh nilai rerata konsentrasi warna kuning.

Teknik pengambilan sampel yang digunakan pada penelitian ini adalah "Quota Sampling". Pada teknik sampling ini setiap responden yang memenuhi kriteria inklusi dimasukkan dalam penelitian dengan jumlah tertentu dalam kurun waktu tertentu (November 2005 sampai Maret 2006), atau sampai jumlah sampel yang diperlukan terpenuhi (6).

Besar sampel yang akan digunakan pada penelitian ini adalah lima orang, dengan pertimbangan etis bahwa penelitian ini dilakukan pada manusia, dan dengan besar 
tersebut secara statistik sudah dapat dilakukan pengujian baik ANOVA maupun uji korelasi-regresi menggunakan SPSS for window untuk mengetahui ada tidaknya efek antar variabel.

Sampel akan diambil atau diteliti setelah orangtua atau keluarga bayi ikterus tersebut bersedia menjadi responden penelitian, kemudian sampel diambil gambarnya (foto) pada area yang menunjukkan tanda ikterus sebelum perlakuan. Kemudian sampel dijemur dibawah sinar matahari pagi, antara pukul 06.00-07.00 selama maksimal 30 menit. Setelah 5 menit pertama, sampel akan diambil gambarnya lagi, demikian juga dengan 5 menit berikutnya, dan dilakukan sampai waktu penjemuran (30 menit) selesai dilakukan.

\section{Bahan dan Instrumen Penelitian}

Bahan penelitian yang digunakan adalah tanda ikterus (kuning) neonatus yang muncul pada kulit, lapisan mukosa maupun pada sklera mata, namun terutama akan diambil pada bagian pipi dan dada, karena area-area tersebut merupakan area yang paling mudah diidentifikasi adanya ikterus fisiologis. Sedangkan instrumen yang digunakan adalah lembar kesediaan untuk menjadi responden (informed consent), sinar matahari pagi, dan kamera digital, Canon Digital Ixus 750, untuk pengambilan gambar bagian tubuh bayi yang menunjukkan tanda ikterus, yaitu pada pipi dan dada.

\section{Cara Kerja dan Pengumpulan Data}

Teknik pengumpulan data yang digunakan adalah dengan menemukan kasus ikterus neonatorum fisiologis pada komunitas (masyarakat) dengan melihat kondisi fisik bayi dan menanyakan pada ibu bayi kapan waktu timbulnya, dan menjadikannya sebagai subjek penelitian apabila memenuhi kriteria inklusi. Kemudian memberikan format persetujuan untuk menjadi responden dan menjelaskan prosedur penelitian. Sebelum dipapar sinar matahari, sampel dilakukan pengambilan gambar pada area pipi dan dada dengan cara yang sesuai dengan kriteria inklusi, kemudian bayi dijemur selama 30 menit dengan prosedur penjemuran yang sesuai, dan pada setiap 5 menit penjemuran bayi difoto pada area yang sama.

\section{Analisis Data}

Jenis analisis statistik yang digunakan pada penelitian ini adalah uji analisis ragam (One Way ANOVA) yang digunakan untuk mengetahui adanya perbedaan antara setiap variasi perlakuan (menit $0,5,10,15,20,25$, dan 30). Kemudian dilanjutkan dengan uji korelasi untuk mengetahui hubungan antar variabel dalam suatu grup. Setelah uji korelasi, dilanjutkan dengan uji regresi untuk mengetahui seberapa besar perbedaan antara setiap variasi tersebut. Serangkaian pengujian ini dilakukan dengan tingkat kemaknaan sebesar $1 \%$. Apabila $p<0,01$ artinya $\mathrm{Ho}$ ditolak dan $\mathrm{H} 1$ diterima, yang berarti ada pengaruh bermakna antara paparan sinar matahari pagi terhadap tanda ikterus pada ikterus neonatorum fisiologis. Untuk menganalisis data menggunakan SPSS for Windows.

\section{Etika Penelitian}

Penelitian ini telah mendapatkan rekomendasi dari Tim Ethical Clearance Fakultas Kedokteran Universitas Brawijaya Malang. Setelah mendapatkan persetujuan dilakukan penelitian dengan menekankan masalah etika yang meliputi:

\section{(1) Lembar persetujuan menjadi responden}

Lembar persetujuan diberikan kepada subyek yang akan diteliti. Peneliti menjelaskan maksud dan tujuan riset yang dilakukan serta dampak yang mungkin terjadi selama dan sesudah pengumpulan data. Jika ibu atau orang tua bayi ikterus bersedia dan mengijinkan anaknya untuk diteliti, maka mereka harus menandatangani lembar persetujuan tersebut. Jika ibu atau orang tua menolak mengijinkan anaknya untuk diteliti, maka peneliti tidak akan memaksa dan tetap menghormati hak-haknya.

(2) Anonimity (tanpa nama)

Untuk menjaga kerahasiaan ibu dan anaknya, peneliti tidak akan mencantumkan namanya pada lembar pengumpulan data, cukup dengan memberi kode pada masing-masing lembar tersebut

(3) Confidentiallity (kerahasiaan)

Kerahasiaan informasi ibu dijamin oleh peneliti, hanya kelompok data tertentu saja yang akan disajikan atau dilaporkan sebagai hasil riset.

\section{HASIL PENELITIAN}

Telah dilakukan penelitian untuk mengetahui pengaruh paparan sinar matahari pagi terhadap penurunan tanda ikterus pada ikterus neonatorum fisiologis. Parameter untuk tanda ikterus adalah nilai rerata warna kuning yang terdapat pada bayi ikterus tersebut yang nilainya telah dianalisis menggunakan program Corel Photo-Paint 12.

Berdasarkan penelitian yang telah dilakukan, didapatkan foto-foto sampel bayi ikterus dan sebagian gambarnya dapat dilihat pada Gambar 1.

Sekilas dari gambar-gambar ikterus diatas terlihat sama, tidak ada perbedaan warna kuning yang bisa diamati dengan semakin lamanya penjemuran, namun apabila fotofoto tersebut dianalisis dengan program Corel Photo-Paint 12 akan ditemukan perbedaan yang cukup signifikan dengan semakin lamanya penjemuran.

Berdasarkan foto-foto sampel diatas, didapatkan hasil pengukuran tanda ikterus, pada saat sebelum dan sesudah perlakuan diberikan selama kurun waktu tertentu (0 menit sampai 30 menit) yang telah dianalisis dengan menggunakan program Corel Photo-Paint 12. Nilai rerata hasil pengukuran tanda ikterus tersebut dapat dilihat pada Tabel 1. 
Berdasarkan tabel, pada sampel ikterus 1 diperoleh rerata nilai tanda ikterus sebelum perlakuan sebesar 152,282. Sedangkan setelah 5 menit perlakuan, diperoleh rerata nilai tanda ikterus sebesar 147,661 . Setelah 10 menit perlakuan, rerata nilai tanda ikterus mengalami penurunan menjadi 139,365 . Demikian juga pada menit ke-15 rerata nilai tanda ikterus adalah 134,023 . Pada menit ke-20 rerata nilai tanda ikterus adalah 129,346 . Pada menit ke-25 rerata nilainya menjadi 120,868 . Dan setelah 30 menit perlakuan diperoleh rerata nilai tanda ikterus sebesar 112,122.

Pada sampel 2, rerata nilai tanda ikterus sebelum perlakuan adalah 151,852. Sedangkan pada menit ke-5, menit ke-10 dan menit ke-15 rerata nilai tanda ikterus masing-masing sebesar 145,512; 137,024; dan 131,31. Nilai tanda ikterus ini selanjutnya terus mengalami penurunan pada menit ke-20, menit ke-25 dan menit ke-30 masing-masing sebesar 126,35; 123,782; dan 116,283.

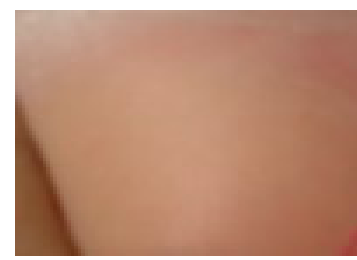

A1

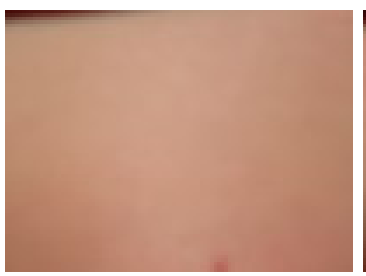

C1

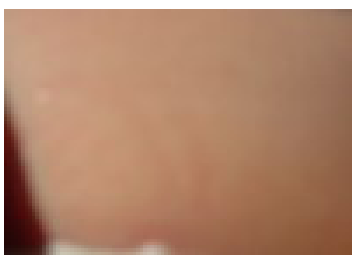

A2

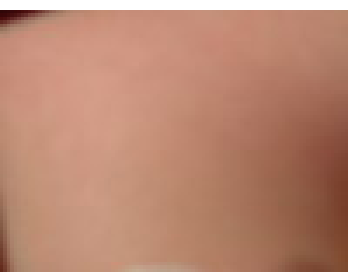

C2

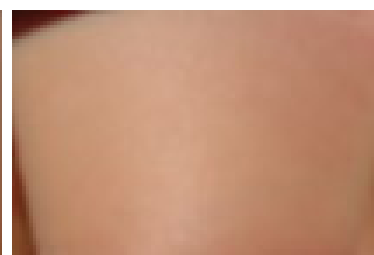

B1

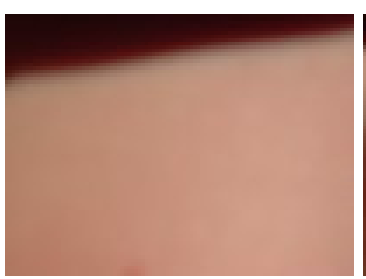

D1

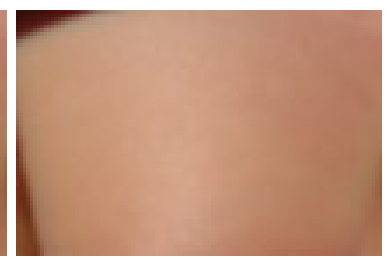

B2

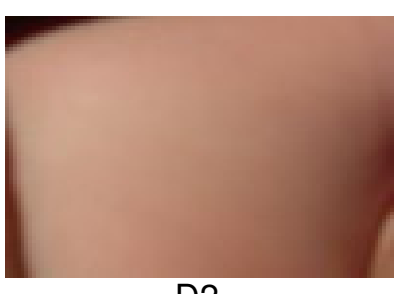

D2

Gambar 1.Kulit bayi ikterus dari ras Asia (suku Jawa) yang diambil dengan menggunakan kamera digital, Canon Digital Ixus 750

Keterangan:

A1: foto pipi kiri sampel ikterus sebelum perlakuan, dengan nilai tanda ikterus yang diperoleh menggunakan Corel Photo-Paint 12 adalah 159,$03 ; 155,29 ; 150,72 ; 150,70$ dan 140,17

A2: foto pipi kanan sampel ikterus sebelum perlakuan, dengan nilai tanda ikterus yang diperoleh dengan menggunakan program yang sama adalah 164,67; 159,89; 153,78; 145,85; dan 142,72. Dari total nilai A1 dan A2 diperoleh rerata sebesar 152,282

B1: foto pipi kiri sampel ikterus setelah 10 menit penjemuran dilakukan, dengan nilai tanda ikterus 136,33; 139,01; 142,98; 141,25; dan 140,53

B2: foto pipi kanan sampel ikterus setelah 10 menit penjemuran, dengan nilai tanda ikterus 137,03; 141,13; 134,65; 138,64; dan 142,10. Dari B1 dan B2 diperoleh rerata 139,365

C1: foto pipi kiri sampel ikterus setelah 20 menit penjemuran, dengan nilai tanda ikterus sebesar 128,21; 128,49; 130,50; 128,16; dan 132,24

C2: foto pipi kanan sampel ikterus setelah 20 menit penjemuran, dengan nilai tanda ikterus sebesar 129,88; 128,44; 127,81; 127,54; 132,24. Dari C1 dan C2 diperoleh rerata nilai tanda ikterus sebesar 129,346

D1: foto pipi kiri sampel ikterus setelah 30 menit penjemuran, dengan nilai tanda ikterus sebesar 121,16; 116,50; 102,50; 105,39; 111,111

D2: foto pipi kanan sampel ikterus setelah 30 menit penjemuran, dengan nilai tanda ikterus sebesar 110,26; 115,50; 109,96; 111,63; 117,21. Dari total nilai D1 dan D2 diperoleh nilai rerata sebesar 112,122 
Tabel 1. Rerata Nilai Tanda Ikterus pada Sampel Penelitian Setelah Dipapar Sinar Matahari yang Dianalis Menggunakan Program Corel Photo-Paint 12

\begin{tabular}{cccccccc}
\hline & Menit 0 & Menit 5 & Menit 10 & Menit 15 & Menit 20 & Menit 25 & Menit 30 \\
\hline Sampel 1 & 152,282 & 147,661 & 139,365 & 134,023 & 129,346 & 120,868 & 112,122 \\
Sample 2 & 151,852 & 145,512 & 137,024 & 131,31 & 126,35 & 123,782 & 116,283 \\
Sample 3 & 158,38 & 154,228 & 146,567 & 143,949 & 141,751 & 137,951 & 102,472 \\
Sample 4 & 166,381 & 159,612 & 154,335 & 145,752 & 141,233 & 134,05 & 121,598 \\
Sample 5 & 137,262 & 1310,99 & 130,428 & 118,897 & 113,93 & 112,514 & 106,88 \\
\hline Jumlah & 766,157 & 738,112 & 707,719 & 673,931 & 652,61 & 629,165 & 559,335 \\
\hline Rerata & 153,2314 & 147,6224 & 141,5438 & 134,7862 & 130,5220 & 125,8330 & 111,8710 \\
\hline
\end{tabular}

Keterangan:

Menit ke 0

Menit ke 5 : nilai rerata tanda ikterus diukur sesudah sampel mendapat perlakuan dijemur selama 5 menit dibawah sinar matahari pagi

Menit ke 10 : nilai rerata tanda ikterus diukur setelah 10 menit perlakuan

Menit ke 15 : nilai rerata tanda ikterus diukur setelah 15 menit perlakuan

Menit ke 20 : nilai rerata tanda ikterus diukur setelah 20 menit perlakuan

Menit ke 25 : nilai rerata tanda ikterus diukur setelah 25 menit perlakuan

Menit ke 30 : nilai rerata tanda ikterus diukur setelah 30 menit perlakuan

Fenomena penurunan nilai tanda ikterus ini juga terlihat pada sampel 5, nilai rerata tanda ikterus sebelum perlakuan adalah 137,262 dan selanjutnya pada menit ke-5, ke-10, ke-15 dan ke-20 setelah penjemuran dilakukan diperoleh nilai tanda ikterus masing-masing sebesar 131,099; 130,428; 118,897; dan 113,93. Pada 10 menit terakhir, yaitu pada menit ke-25 dan menit ke-30 diperoleh nilai tanda ikterus masing-masing sebesar 112,514 dan 106,88.

Masing-masing nilai rerata tanda ikterus ini direrata lagi dari kelima sampel, berdasarkan lamanya waktu penjemuran, dan diperoleh rerata akhir pada menit ke-0 sebesar 153,2314. Pada menit ke-5, ke-10, ke-15, dan ke20 masing-masing rerata akhirnya adalah 147,6224; 141,5438; 134,7862; dan 130,5220. Pada menit ke-25 dan ke-30 nilai rerata akhir menjadi 125,8330 dan 111,8710. Secara ringkas, nilai rerata total pada masing-masing waktu penjemuran dapat digambarkan pada Tabel 2.

Tabel 2. Nilai Rerata Tanda Ikterus

\begin{tabular}{cc}
\hline \multirow{2}{*}{ Waktu } & Tanda lkterus \\
\cline { 2 - 2 } & Mean \pm SD \\
\hline 0 menit & $153,2314 \pm 10,69 \mathrm{e}$ \\
5 menit & $147,6224 \pm 10,78$ de \\
10 menit & $141,5438 \pm 9,19$ cde \\
15 menit & $134,7862 \pm 10,83 \mathrm{bcd}$ \\
20 menit & $130,5290 \pm 11,56 \mathrm{abc}$ \\
25 menit & $125,8330 \pm 10,25 \mathrm{ab}$ \\
30 menit & $111,8710 \pm 7,54 \mathrm{a}$ \\
\hline
\end{tabular}

Keterangan:

superscript pada masing-masing nilai rerata tanda ikterus diatas menunjukkan tingkat kemaknaan atau signifikansi.
Berdasarkan Tabel 2 diatas perbedaan notasi huruf pada nilai rerata menunjukkan adanya perbedaan yang bermakna dengan semakin lamanya waktu penjemuran, demikian pula notasi huruf yang sama pada nilai rerata tersebut menunjukkan tidak ada perbedaan yang bermakna dengan semakin bertambahnya waktu penjemuran

\section{Analisis Hasil Penelitian}

Foto-foto sampel ikterus yang telah didapatkan seperti pada Gambar 1. diatas selanjutnya dianalisis dengan menggunakan program Corel Photo-Paint 12. Hal ini dilakukan dengan pertimbangan bahwa warna kuning yang terlihat pada foto-foto tersebut merupakan data kualitatif (berupa warna kuning) sehingga perlu diubah menjadi data kuantitatif (berupa angka atau rasio konsentrasi warna) yang salah satu caranya adalah dengan menggunakan program Corel Photo-Paint 12.

Data pengaruh paparan sinar matahari pagi terhadap tanda ikterus pada penelitian ini, yang sudah berupa data kuantitatif, selanjutnya dilakukan serangkaian pengujian dengan uji analisis ragam (One way ANOVA) dengan menggunakan nilai rerata tiap sampel. Namun sebelum melakukan analisis data dengan menggunakan ANOVA yang merupakan salah satu uji statistik parametrik, maka diperlukan uji asumsi normalitas data untuk mengetahui apakah data mempunyai sebaran (distribusi) normal, mempunyai ragam yang homogen, dan galat (error) penelitian bersifat acak dan bebas. Hasil uji normalitas data ini menunjukkan bahwa data variabel tersebut menyebar mengikuti sebaran normal. Selanjutnya, setelah diperoleh kesimpulan demikian maka dapat dilanjutkan pengujian dengan menggunakan ANOVA. Dari pengujian ini diperoleh hasil deskripsi variabel. Kemudian dilanjutkan dengan uji kesamaan varians (ragam) populasi dan diperoleh hasil 
bahwa varians (ragam) populasi adalah homogen (sama) sehingga dapat dilakukan pengujian lebih lanjut.

Setelah pengujian dengan ANOVA, selanjutnya dilakukan uji pembandingan berganda (Post Hoc Test) dan diperoleh tabel Multiple Comparison yang merupakan pengujian lanjut berdasarkan uji LSD (Least Square Differensial) atau BNT (Beda Nyata Terkecil). Uji nyata terkecil dengan BNT-nya digunakan apabila pembandingan yang dilakukan terencana, untuk perlakuan yang tidak terlalu banyak $(p \leq 5)$, dan $F_{\text {hitung }}$ harus $>F_{\text {tabel, }}$, selain itu data harus homogen, tidak bisa digunakan pada data kualitatif, dan asumsi data terpenuhi (8). Dan diperoleh hasil seperti pada Tabel 2. pada tabel tersebut tampak bahwa ada perbedaan bermakna dengan semakin lamanya penjemuran.

Setelah uji LSD diatas, selanjutnya dapat dilakukan uji korelasi dan regresi. Regresi linier sederhana digunakan untuk mengetahui signifikansi adanya pengaruh dari dilakukan beberapa tahapan untuk mencari hubungan antara variabel independen dan variabel dependen. Berdasarkan hasil analisis tersebut dapat diketahui bahwa tanda ikterus mempunyai hubungan yang erat secara signifikan dengan 7 variasi lamanya waktu paparan sinar matahari pagi yang diuji, dengan nilai signifikansi $>0,01$ sebesar 0,00 dan nilai korelasi (r) sebesar - 0,986. Artinya peningkatan variasi lamanya waktu paparan sinar matahari pagi akan menurunkan tanda ikterus (karena koefisien korelasi bernilai negatif). Demikian pula sebaliknya. Seberapa besar penurunan tanda ikterus yang disebabkan oleh adanya tujuh variasi lamanya waktu paparan sinar matahari pagi, dapat diketahui dengan menggunakan analisis bentuk hubungan (regresi), karena dari uji korelasi belum bisa menjelaskan hal tersebut. Dari analisis regresi diperoleh tabel Model Summary yang memberikan informasi tentang nilai korelasi sebagai pengukur ketepatan garis regresi dalam menjelaskan variasi nilai variabel independent serta nilai durbin watson ( $\mathrm{dw}$ ). Kolom kedua dan ketiga menyajikan ukuran derajat keeratan hubungan antara variabel, serta besarnya pengaruh variabel bebas terhadap variabel dependen $Y$. Uji hipotesis ini menggunakan simple regresion yang bertujuan untuk mengetahui apakah variabel waktu paparan sinar matahari pagi berpengaruh terhadap tanda ikterus. Adapun hasil yang diperoleh adalah:

a. Koefisien korelasi (R) sebesar 0,986 menyatakan besarnya derajat keeratan hubungan antara variabel tanda ikterus dengan variabel bebas (waktu paparan sinar matahari pagi) serta adanya pengaruh diantara variabel-variabel bebas (return pasar) terhadap variabel return saham $(Y)$

b. Koefisien determinasi (R square $\left.=r^{2}\right)$ sebesar 0,972 menyatakan besarnya pengaruh variabel bebas (waktu paparan sinar matahari pagi) dengan variabel tanda ikterus. Sedangkan koefisien determinasi $=$ Adjusted $R$ square sebesar 0,966 adalah koefisien determinasi yang telah terkoreksi dari faktor bias (kesalahan). Dari nilai R square dapat diartikan bahwa $97,2 \%$ keragaman variabel tanda ikterus ditentukan oleh waktu paparan sinar matahari pagi. Sedangkan sisanya 2,8\% ditentukan oleh faktor lain (di luar persamaan model regresi)

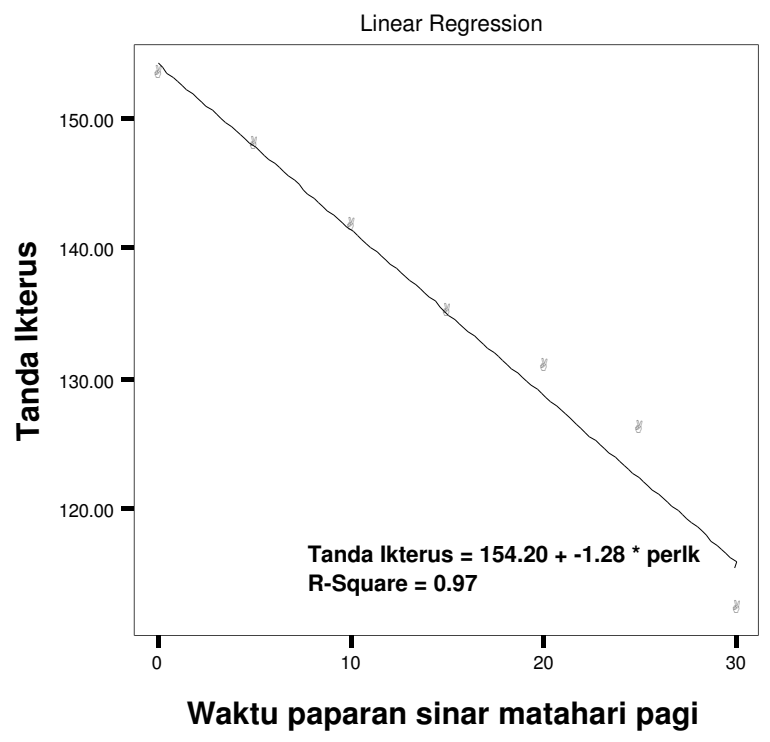

Gambar 2. Grafik Linearitas Nilai Tanda Ikterus dan Waktu Paparan Sinar Matahari Pagi 
Selanjutnya dari grafik tersebut diperoleh rumusan $Y$ (tanda ikterus) $=154,203-1,276 \times$ (waktu paparan sinar matahari pagi). Berdasarkan rumusan tersebut dapat diimplikasikan:

- Apabila tidak ada pengaruh dari waktu paparan sinar matahari pagi, maka tanda ikterus diprediksikan akan tetap mengalami peningkatan sebesar 154,203 (karena nilai konstanta bernilai positif)

- Apabila waktu paparan sinar matahari pagi semakin meningkat, maka hal ini secara signifikan dapat menurunkan tanda ikterus sebesar 1,276 (karena koefisien $\mathrm{X}$ bernilai negatif). Demikian pula sebaliknya, kurangnya waktu paparan sinar matahari pagi akan dapat meningkatkan tanda ikterus sebesar 1,276

\section{DISKUSI}

Ikterus merupakan gejala yang sering ditemukan pada bayi baru lahir dan ditandai dengan munculnya warna kuning pada permukaan kulitnya. Hal ini dapat terjadi karena kadar bilirubin bebas yang ada dalam tubuhnya melebihi normal sehingga bilirubin bebas yang larut dalam lemak tersebut menjadi terlihat di permukaan kulit (lapisan subcutan) yang sebagian besar kandungannya adalah lemak. Pada penelitian ini, perlakuan berupa menjemur (memapar) bayi ikterus fisiologis di bawah sinar matahari pagi dilakukan dengan tujuan untuk mengetahui pengaruh paparan sinar matahari pagi sehingga dapat mengurangi tanda ikterus (warna kuning) yang tampak di kulit bayi. Pada bab ini akan dibahas lebih lanjut tentang tanda ikterus yang diperoleh sebelum dan setelah dipapar sinar matahari pagi, serta perbedaan tanda ikterus tersebut antara sebelum dan sesudah dipapar sinar matahari pagi.

\section{Tanda Ikterus Bayi Sebelum Dipapar Sinar Matahari Pagi}

Dari data sampel ikterus yang telah diperoleh melalui pengambilan gambar (foto) menggunakan kamera digital Canon Digital Ixus 750 pada saat sebelum penjemuran dilakukan, diperoleh hasil gambar atau foto pada menit ke-0 seperti pada Gambar 1. Gambar-gambar yang menunjukkan warna kuning tersebut kemudian diolah dengan menggunakan program Corel Photo-Paint 12 dan diperoleh nilai konsentrasi warna kuning yang ditunjukkan dengan nilai rerata pada kelima sampel sebesar 153,2314. Program Corel Photo-Paint 12 digunakan dalam penelitian ini dengan pertimbangan karena kemudahannya dalam mengoperasikan, dan program tersebut sudah terstandart untuk dapat digunakan mencari nilai konsentrasi warna pada sebuah foto atau gambar. Selain itu, penggunaan program ini dalam penelitian dengan mengambil foto atau gambar bayi ikterus bukan merupakan tindakan invasif seperti mengambil sampel darah untuk pengujian bilirubin, sehingga dapat meminimalkan resiko terjadinya kerugian akibat penelitian, seperti infeksi, kecacatan, dan lain sebagainya yang tentunya tidak diharapkan baik oleh peneliti maupun oleh pihak yang diteliti.

Adapun nilai rerata tanda ikterus pada menit ke-0 tersebut cukup tinggi karena bilirubin bebas yang larut dalam lemak banyak terdapat pada permukaan kulit bayi, terutama tampak pada pipi dan dada.

\section{Tanda Ikterus Bayi Setelah Dipapar Sinar Matahari Pagi}

Pada menit ke-5 dan seterusnya sampai menit ke-30 dilakukan pengambilan gambar menggunakan kamera digital yang sama, Canon Digital Ixus 750, dan diperoleh gambar-gambar pipi bayi ikterus seperti pada Gambar 1. Selanjutnya, dengan teknik yang sama, gambar-gambar tersebut diolah menggunakan program Corel Photo-Paint 12 dan diperoleh nilai rerata tanda ikterus dari kelima sampel pada menit ke-5 sebesar 147,6224.

Pada menit ke-10 diperoleh nilai rerata tanda ikterus dari kelima sampel sebesar 141,5438 . Selanjutnya pada menit ke-15 diperoleh nilai rerata tanda ikterus sebesar 134,7862 . Nilai rerata tanda ikterus ini pada menit-menit selanjutnya terus memperlihatkan penurunan seperti pada menit ke-20 diperoleh nilai rerata tanda ikterus sebesar 130,5220 , pada menit ke-25 sebesar 125,8330 , sampai akhirnya pada menit ke-30 menunjukkan nilai rerata tanda ikterus sebesar 111,8710.

Teknik pengambilan gambar (foto) yang dilakukan pada sampel adalah dengan melepaskan penutup kepala bayi agar kepala, yang merupakan bagian terluas dari tubuh bayi, terpapar sinar matahari lebih banyak. Kemudian memposisikan kepala bayi membelakangi sinar matahari. Hal ini harus diperhatikan pada saat menjemur bayi, apapun kondisinya, karena apabila bayi dijemur dengan posisi kepala menghadap sinar matahari akan dapat menimbulkan kerusakan retina yang pada akhirnya dapat berakibat terjadinya kebutaan pada bayi dan efek ini jelas akan sangat merugikan bagi bayi.

Diperhatikan juga kondisi cuaca pada saat itu. Apabila cuaca cerah, yang berarti bahwa pada saat penjemuran tersebut tidak mendung maupun hujan dan tidak berangin, maka penjemuran dapat dilakukan. Sebab apabila suasana pada saat penjemuran berangin, akan dapat menimbulkan gangguan pada bayi tersebut. Sehingga ketika penelitian ini dilakukan, penderita ikterus tersebut dijemur di dalam ruangan terbuka yang sinar matahari dapat masuk dengan bebas tanpa penghalang apapun, termasuk kaca jendela.

Pada saat penelitian dilakukan, pemaparan bayi ikterus di bawah sinar matahari dilakukan antara pukul 06.00-07.00. Hal ini dilakukan berdasarkan penelitian Cheremisinoff dan Regino (1978) yang menguji tentang kekuatan radiasi sinar matahari yang dilakukan selama $1 \mathrm{x}$ 
24 jam yang berhasil menemukan bahwa antara pukul 06.00-07.00 radiasi sinar matahari hampir tidak ada sama sekali atau nol persen (Gambar 2). Berdasarkan penelitian tersebut diatas, maka penelitian ini dengan memapar bayi ikterus dibawah sinar matahari dilakukan dengan pertimbangan untuk meminimalkan efek samping dari penjemuran seperti efek sinar ultraviolet yang dapat menimbulkan luka bakar pada kulit, dehidrasi akibat paparan sinar matahari yang terlalu kuat seperti pada siang hari, hingga kemungkinan terjadinya keganasan (kanker) kulit akibat paparan sinar matahari yang terlalu lama.

Lamanya penjemuran pada saat penelitian dilakukan adalah 30 menit. Hal ini dilakukan dengan pertimbangan bahwa menjemur bayi di bawah sinar matahari sebaiknya dilakukan maksimal selama 30 menit, sebab penjemuran yang lebih dari itu dikhawatirkan akan terjadi dehidrasi pada bayi, luka bakar pada kulit akibat terlalu lama dijemur, dan resiko terjadi keganasan pada kulit. Kemungkinan ini juga ditunjang dengan kondisi organ-organ neonatus, terutama kulit, yang masih imatur sehingga mudah terpicu untuk menjadi ganas (9).

Selama penjemuran dilakukan, ibu tidak diijinkan memberikan ASI pada bayinya karena di dalam nutrisi, terutama ASI, terdapat komponen yang dapat mempengaruhi kadar bilirubin bayi ikterus, namun sampai saat ini belum diketahui komponen apakah yang dimaksud (9). Berdasarkan informasi yang diperoleh dari ibu diketahui bahwa sebelum dijemur bayi tersebut sudah diminumi ASI kurang lebih 30-15 menit sebelumnya. Sehingga kemungkinan dapat semakin mempengaruhi terjadinya penurunan tanda ikterus pada bayi. Sebab menurut Ismaelia, 2006, protein maupun glukosa yang terkandung di dalam ASI tersebut berguna untuk mengurangi timbunan bilirubin dan mengangkut bilirubin bebas ke dalam hepar (9).

\section{Perbedaan Tanda Ikterus Bayi Sebelum dan Setelah Dipapar Sinar Matahari Pagi}

Seperti yang tersaji pada Gambar 1, dari foto-foto tersebut sangat sulit untuk diketahui bahwa warna kuning yang tampak pada kulit sampel ikterus berkurang atau semakin memudar seiring dengan bertambahnya waktu penjemuran. Hal ini juga ditunjang dengan teori bahwa umumnya warna kuning yang tampak pada kulit dan membran mukosa bayi ikterus akan terlihat menghilang setelah lebih kurang 7 hari (10). Sehingga apabila penilaian warna kuning ini dilakukan dengan pengamatan oleh mata saja, dengan rentang waktu pengamatan yang singkat, maka akan dapat disimpulkan bahwa menjemur bayi kuning di bawah sinar matahari pagi tidak akan bermanfaat apaapa, padahal menjemur bayi kuning ini sering disarankan oleh tenaga kesehatan berdasarkan sumber dari Nelson (1996) dan Dworkin (2000) bahwa bilirubin dapat menyerap energi cahaya pada sinar matahari yang selanjutnya akan membuat bilirubin tersebut mudah diekskresikan. Oleh karena itu diperlukan suatu cara untuk menilai warna kuning tersebut dengan cara mengubah data kuantitatif menjadi data kualitatif agar pengaruhnya dapat diketahui dan dihitung dengan angka yang salah satu caranya adalah menggunakan program Corel Photo-Paint 12.

Dari analisis warna kuning yang diperoleh menggunakan program tersebut didapatkan nilai rerata tanda ikterus pada kelima sampel seperti pada Tabel 1. Kemudian dari nilai rerata tersebut dianalisis perbedaannya pada tiap variasi waktu seperti pada Tabel 2 untuk mendapatkan signifikansi perbedaannya.

Berdasarkan Tabel 2 tersebut, dapat disimpulkan bahwa terdapat perbedaan yang nyata pada nilai rerata tanda ikterus setelah 30 menit penjemuran. Berdasarkan hasil analisis tersebut, maka dapat disimpulkan bahwa waktu penjemuran yang efektif, yang dapat memberikan pengaruh secara bermakna, adalah selama 30 menit di bawah sinar matahari pagi. Namun hal ini memerlukan pengujian lebih lanjut tentang efektivitas dan spesifisitas lamanya waktu penjemuran.

Setelah pengujian diatas, dilanjutkan dengan serangkaian pengujian lainnya, salah satunya adalah uji korelasi, diperoleh hasil bahwa korelasi ( $r$ ) sebesar $-0,986$ dengan nilai signifikansi $(p)>0,01$ sebesar 0,000 . Dari hasil analisis ini dapat disimpulkan bahwa tanda ikterus mempunyai hubungan yang erat secara signifikan dengan tujuh variasi lamanya waktu paparan sinar matahari pagi. Sehingga dapat diambil kesimpulan bahwa tanda ikterus akan semakin menurun dengan semakin lamanya waktu paparan sinar matahari pagi. Penurunan tanda ikterus ini sesuai dengan Nelson (1996) dan Dworkin (2000), yang mengemukakan bahwa kandungan sinar matahari yang dapat memberikan pengaruh berupa penurunan tanda ikterus adalah sinar biru, yang merupakan komponen sinar ultraviolet. Bilirubin dalam kulit akan menyerap cahaya secara maksimal dalam batas wilayah warna biru (mulai dari $420-470 \mathrm{~nm}$ ). Bilirubin tersebut akan menyerap energi cahaya, yang melalui fotoisomerasi mengubah bilirubin bebas yang bersifat toksik menjadi isomer-isomernya, Lumirubin serta $4 Z$ dan 15E-bilirubin, yang pada akhirnya akan dapat diekskresi oleh hati dan ginjal tanpa memerlukan konjugasi $(3,11)$. Sinar biru yang merupakan kandungan dalam sinar matahari tersebut dapat mengikat bilirubin bebas di permukaan tubuh (kulit) sehingga mengubah sifat molekul bilirubin bebas yang semula larut dalam lemak menjadi fotoisomer yang larut dalam air. Dengan pengubahan sifat molekul yang dilakukan sinar biru ini pada akhirnya akan dapat mengurangi tanda ikterus yang tampak pada bayi, sehingga pada akhirnya bayi tersebut akan sembuh dengan level bilirubin bebas dalam batas normal. 
Untuk mengetahui seberapa besar penurunan tanda ikterus tersebut dapat diketahui melalui analisis bentuk hubungan (regresi). Berdasarkan pengujian tersebut diperoleh tabel Model Summary yang menunjukkan hasil yaitu koefisien korelasi (R) sebesar 0,986 yang menunjukkan bahwa terdapat keeratan hubungan antara tanda ikterus dengan waktu paparan sinar matahari. Selain itu juga diperoleh hasil koefisien determinasi ( $R$ square) sebesar 0,972 dan koefisien determinasi (adjusted $R$ square) sebesar 0,966, yang berarti bahwa 97,2\% tanda ikterus ditentukan oleh waktu paparan sinar matahari pagi, sedangkan sisanya $2,8 \%$ ditentukan oleh faktor lain, dalam hal ini termasuk nutrisi salah satunya.

Setelah diperoleh hasil analisis demikian, analisis dilanjutkan dengan uji $\mathrm{F}$ dan diperoleh grafik linearitas seperti pada Gambar 2. Berdasarkan rumusan pada grafik tersebut dapat diimplikasikan bahwa apabila tidak ada pengaruh sama sekali dari waktu paparan sinar matahari pagi, yang berarti bahwa bayi-bayi ikterus tersebut tidak mendapat penanganan apapun, maka tanda ikterus diperkirakan akan tetap mengalami peningkatan sebesar 154,203. Namun apabila waktu paparan sinar matahari semakin meningkat, maka hal ini secara signifikan dapat menurunkan tanda ikterus sebesar 1,276. Demikian pula sebaliknya, semakin sedikit waktu paparan sinar matahari pagi akan semakin meningkatkan tanda ikterus sebesar 1,276.

Berdasarkan hasil analisis statistik diatas dapat disimpulkan bahwa apabila waktu penjemuran semakin meningkat, diperkirakan setiap menit yang ditambahkan selama penjemuran berlangsung akan dapat menurunkan tanda ikterus sebesar 1,276 per menitnya. Sebagai contoh, apabila bayi ikterus $A$ setelah dilakukan pengambilan gambar diperoleh nilai rerata tanda ikterus sebesar 160,00, maka setelah dilakukan penjemuran selama 30 menit pada satu hari tersebut akan menurunkan nilai tanda ikterusnya sebesar 38,38 (dari hasil perhitungan 1,276 dikali 30). Demikian pula setelah 30 menit berikutnya pada penjemuran hari kedua maupun pada hari-hari berikutnya. Sehingga apabila penjemuran dilakukan setiap hari dengan lama penjemuran setiap harinya adalah 30 menit, maka diperkirakan tanda ikterus akan menghilang setelah dijemur selama 5 hari atau lebih tergantung dari rerata nilai tanda ikterus yang didapatkan. Hasil perhitungan ini sesuai dengan teori di beberapa literatur yang menyatakan bahwa warna kuning yang tampak pada kulit maupun selaput mukosa bayi ikterus fisiologis akan menghilang dalam kurun waktu kurang lebih satu minggu atau maksimal hingga 10 hari (1).

Berdasarkan hasil analisis tersebut diatas dapat disimpulkan bahwa tindakan menjemur bayi kuning di bawah sinar matahari yang biasanya dilakukan oleh ibu-ibu dan juga yang dilakukan pada penelitian ini merupakan hal yang bermanfaat bagi perbaikan kondisi penderita ikterus. Karena penjemuran yang dilakukan, berdasarkan aturan- aturan dari teori-teori yang pernah ada akan menimbulkan efek positif bagi penderita ikterus neonatorum fisiologis, yaitu dengan menurunkan nilai rerata tanda ikterus. Dan apabila kegiatan menjemur bayi ini tetap dilanjutkan, terutama dengan cara-cara yang benar, pada akhirnya akan terjadi kesembuhan pada penderita tersebut, dengan semakin berkurangnya tanda ikterus dan level bilirubin bebas dalam darah. Sehingga pada akhirnya nanti kadar bilirubin bebas dalam darah tetap berada dalam batas normal dan warna kuning yang tampak pada kulit mapun selaput mukosa lain akan hilang.

Kelemahan dalam penelitian ini adalah jumlah sampel yang sedikit, 5 bayi ikterus fisiologis, dikarenakan pertimbangan waktu, biaya dan tenaga. Selain itu juga variasi waktu penjemuran sedikit ( 7 variasi waktu penjemuran). Tujuh variasi waktu ini meliputi menit ke-0, menit ke-5, menit ke-10, menit ke-15, menit ke-20, menit ke25 , dan menit ke-30. Kurangnya variasi ini disebabkan karena keterbatasan waktu penjemuran, maksimal 30 menit. Sesuai Ismaelia (2006) yang menyebutkan bahwa dalam satu hari, penjemuran maksimal dilakukan selama 30 menit. Sedangkan apabila penelitian dilanjutkan keesokan harinya, maka faktor lain di luar sinar matahari akan banyak berpengaruh, seperti nutrisi (ASI atau PASI) dan proses pematangan hepar bayi. Selain hal tersebut diatas, kelemahan lain dalam penelitian ini adalah pengaruh sinar matahari pagi terhadap tanda ikterus baru dianalisis berdasarkan lamanya waktu penjemuran, belum pada tingkat sel atau molekuler agar dapat diketahui berapa jumlah energi sinar matahari yang ditangkap atau diserap oleh bilirubin bebas di kulit bayi ikterus. Sehingga berdasarkan kelemahan-kelemahan tersebut, dapat dilakukan penelitian yang sama atau bahkan penelitian yang lebih lanjut tentang pengaruh paparan sinar matahari pagi terhadap tanda ikterus ini.

\section{KESIMPULAN}

1. Paparan sinar matahari pagi berpengaruh terhadap penurunan tanda ikterus pada ikterus neonatorum fisiologis

2. Waktu penjemuran yang efektif adalah selama 30 menit

3. Program Corel Photo-Paint 12 bisa digunakan sebagai metode penentuan derajat ikterus

\section{SARAN}

1. Perlu dilakukan uji klinik untuk membandingkan penggunaan bilirubinometer melalui sampel darah dengan metode Corel Photo-Paint 12

2. Perlu dilakukan penelitian ulang dengan metode yang sama, dengan jumlah sampel lebih banyak

3. Perlu dilakukan penelitian lebih lanjut tentang seberapa besar pengaruh lain diluar sinar matahari, seperti 
nutrisi, obat-obatan dan faktor-faktor lain yang belum diketahui terhadap penurunan tanda ikterus

4. Perlu dilakukan pengujian lebih lanjut tentang efektivitas lamanya waktu pemaparan (penjemuran) bagi bayi ikterus fisiologis

5. Perlu dilakukan lebih lanjut tentang penggunaan program Corel Photo-Paint 12 sebagai metode penentuan derajat ikterus pada ikterus neonatorum patologis

6. Perlu dilakukan uji efektivitas dan spesifisitas metode penentuan derajat ikterus dengan menggunakan program Corel Photo-Paint 12

7. Perlu dilakukan penelitian lebih lanjut tentang pengaruh paparan sinar matahari pagi pada tingkat sel atau molekuler

\section{DAFTAR KEPUSTAKAAN}

1. Wiknjosastro, Hanifa. Ilmu Kebidanan. Jakarta: Pusat: Yayasan Bina Pustaka Sarwono Prawirohardjo. 1999.

2. Widjanarko, Hendra Gunawan (email protected). Bayi Kuning. 29 Januari 2001. Email kepada Diah (email protected). diakses 18 Maret 2005, pukul 08.15

3. Nelson. IImu Kesehatan Anak. Volume 1. Jakarta: EGC. 1996.

4. Yong, Mohamed Yosri Mohamed. Demam Kuning-Jaundis pada Bayi (http://www.geocities.com/alam_penyakit/PenyakitDemamKuning Jaundis) diakses tanggal 18 Maret 2005, pukul 09.00

5. Notoatmodjo, Soekidjo. Metodologi Penelitian Kesehatan. Jakarta: Penerbit Rineka Cipta. 2002.

6. Nursalam dan Siti Pariani. Pendekatan Praktis Metodologi Riset Keperawatan. Jakarta: CV. Infomedika. 2001.

7. Sastroasmoro dan Ismael. Dasar-dasar Metodologi Penelitian Klinis. Edisi kedua. Jakarta: Sagung Seto. 2002.

8. Yitnosumarno, Sunyoto. Percobaan Perancangan, Analisis, dan Interpretasinya. Jakarta: PT. Gramedia Pustaka Utama. 1993.

9. Ismaelia. (balita-anda) Ragam Terapi Untuk Bayi Kuning. 2006 http://www.mail-archieve.com/balita-anda@balita anda.com/msg114462.html diakses 1 September 2006, pukul 13.30)

10. Kavindra. (balita-anda) Artikel Bahaya Bayi Kuning. 2005. (http://www.mail- arcieve.com/balita-anda@balitaanda.com/msg97329.html. diakses 1 September 2006, pukul 13.30)

11. Dworkin, Paul H. Pediatrics National Medical Series for Independent Study. $4^{\text {th }}$ edition. USA: Lippincott Williams and Wilkins. 2000. 